MICHAŁ CHOMICKI

\title{
Organizational sensory systems of Polish enterprises in the context of cooperative relationships
}

Michał Chomicki, Ph.D., Poznań University of Economics and Business, Faculty of Management, Poland, ORCID: 0000-0002-3918-7891.

\section{Introduction}

The aim of this paper is to indicate the relationship between the shape of organizational sensory systems of Polish companies and beneficialness of the shape of cooperative relations between these companies with particular kinds of cooperators. In today's business environment, well-established cooperative relationships allow for a lasting competitive advantage. The significance of cooperative relationships can be demonstrated by the concept of relational capital in which the surplus value of an enterprise is considered when its estimation by classical valuation methods, both accounting and financial, does not coincide with objectively perceived total value of the enterprise. It was assumed that the organization's relations with the elements of the task environment (the relations with the cooperating entities in particular) are, at its basis, of a voluntary nature, so they can be shaped by individual organizations. It was also assumed that the shape of the organizational sensory system influences the shape of the cooperative relations, and in consequence it influences the potential benefits associated with it. 


\section{Cooperative relationships}

According to the resource paradigm of the organization, relational resources are important to the functioning of this organization. The source of these resources are various inter-organizational activities (Wójcik-Karpacz 2012, p. 22), and inter-organizational relations in particular. These relationships tie organizations and external entities as equal peers. In principle, these peers are suppliers, clients and competitors, whose importance as actors of horizontal relations has increased over the last few decades (Okada 2008).

The concept of organization's relations with the environment, especially with the elements of the task environment, can refer to two kinds of relationships. Firstly, these bonds can be interactive, that means that they can involve the exchange of resources, including knowledge. Secondly, relationships may be noninteractive when organizations share some common features, such as cognitive systems, value systems (Porac, Ventresca, Mishina 2002) or identity and strategy derived from isomorphism (Dyer, Nobeoka 2000). Interactive relationships with the environment represent relatively durable transactions, flows of resources, and other types of connections between the organization and at least one element from its environment (Oliver 1990). Such relationships in the light of the resource-based view sum up to the relational capital. A particular type of relationships with the environment are inter-organizational relationships that can be perceived as the outcome of a process in which at least two organizations have formed strong ties and extended their social, economic and technical services to reduce costs or increase organizational value, and in consequence to obtain mutual benefits (Anderson, Narus 1991).

Relationships between companies can be analyzed in respect to different areas and from multiple perspectives. C. Lane and R. Bachmann proposed an analysis of relationships at three levels - interpersonal, organizational and institutional (Lane, Bachmann 1997). The core of the relationship can be based on interpersonal contacts, contracts or membership in associations uniting organizations that are present in the given sector - these are called the institutional relationships.

Contract-based relationships has the greatest importance for the organization's activities, as contracts are the basic instrument for regulating business. Agreements between cooperators can be broken down according to the area of the contract-based regulations. This way a few different kinds of contracts can be distinguished, including development, purchasing, production, marketing and distribution agreements (Urban, Vendemini 1992, p. 131). The extent to which the given areas are regulated by the agreements can thus be considered as a measure

MICHA $\mathrm{CHOMICKI}$ 
of the interconnection of the partners. These relationships are generally formed by the manifestation of the will of the cooperation. The cooperative relationships can be divided into arm's length contractual relations, which do not form an implicit long-term commitment and obligational relations that impose such an obligation. The criteria that differentiate these two types of relationships are interdependence and time span for reciprocity (Sako 1992, p. 4).

Considering the above remarks on the perception of relationships, it is necessary to adopt the definition according to which the cooperative relationships are vertical or horizontal ties between cooperators (i.e. the organization and its suppliers, customers and cooperating competitors), maintaining the repetitive flows of tangible and intangible resources to obtain mutually satisfying benefits.

The dynamics of the contemporary business environment justify a need to have a broader look at interactions between organizations. These entities do not limit their actions just to analyze their relationships only in the context of inter-organizational relationships, but more and more often they also consider the dynamics of the network structures in which they participate. According to M. Ebers (1997), inter-organizational networks can be defined as certain bonds that establish repetitive, partner-specific relationships based on an exchange of a definite (often determined as a moment of reaching a common goal or a desire to terminate a relationship for another reason) or an indefinite period between finite number of business actors. These actors maintain individual control over their resources, but in some cases, they negotiate or co-ordinate their use. This is different from the market as a structure of resources allocation, where one-sided coordination of plans and actions is preferred. In addition, as a part of business networks, participants communicate a wider range of information to each other than in case of separate market exchanges. Inter-organizational networks differ from the hierarchy (enterprise), understood as a structure of resource allocation, primarily because their participants do not create a new economic entity, and thus maintain a unilateral control over their own resources. B.R. Barringer, J.S. Harrison (2000, p. 387) presented a concept that inter-organizational networks are constellations of enterprises more often organized with social contracts as underlying bonds rather than legally binding contracts as a foundation. According to the Authors of this concept, the network is a separate form of cooperation alongside other ways of the allocation of resources (i.e. market and hierarchy). It should be noted, however, that in the networks themselves there are different forms of cooperation between the participants, so that the relationship between the network and the different types of cooperation (relations) can be treated as analogous to the relation of the whole to a part.

Organizational sensory systems of Polish enterprises in the context of cooperative 
T. Ritter, I.F. Wilkinson and W.J. Johnston (2004, p. 179) made a clear distinction between the term of inter-organizational relations and the business network by describing the inter-organizational relationships as components of business networks. The authors described five levels of business activity from the level of independent actions of individual actors to the complex network links between them. Independent actors conduct business activities without entering relationships with other entities. Two-sided relationships (diads) are the relationships between two different actors. A relationship portfolio is a situation in which individual actors are linked by relationships to more participants. The level of interrelated relationships presents the configuration of the actor's relations and the relationships in which the participants of his relationship portfolio remain. At the level of the business network, the analysis is made of all relationships between the elements of a given population. As can be seen, the primary object of analysis in inter-organizational relationships are the relationships between two entities (diads).

E. Urbanowska-Sojkin (2003, p. 126), who distinguished twelve types of cooperation links between enterprises, arranged a proposal for the gap between the market and the hierarchy, ranking them in order from the lowest level of cooperation to the highest: trade, information exchange, R\&D assistance, technical assistance, leasing, co-production, franchising, consortium, joint venture, buyout and merger. This concept rightly does not consider the structure of inter-organizational networks as a separate category. This can be explained on the one hand by its elusive character of inter-organizational relations and on the other by their high degree of flexibility - for example both joint ventures and $R \& D$ assistance are elements of inter-organizational networks. Thus E. Urbanowska-Sojkin presented various types of relationships that are elements of inter-organizational networks.

D. Latusek-Jurczak (2014) presented a breakdown of forms of cooperation with co-operators based on two criteria. The first criterion of the division was the coordination mechanisms of relations and as a second criterion she has chosen the motivation to enter business relationships, among which she pointed out the benefits of standardization, the benefits of diversity and the collaborative acquisition of knowledge. However, this is not an exhaustive catalog of motives for undertaking inter-organizational co-operation, although the Author undoubtedly pointed out the most important values of selected criteria. Especially important is the motive of the joint acquisition of knowledge by the parties of the relationship. 


\section{Methodology}

To identify the relationship between the organizational sensory systems and the shape of cooperative relations, it was decided to adopt several assumptions related to the measures that were used. Organizational sensory system was defined as a part of organizational structure consisting of means to identify and analyze events occurring in the environment and inside the organization to quickly respond to their appearance. Organizational sensory systems have been described by indications to the monitoring frequencies of internal functional units and the environment. Due to the equifinal character of the relationship maintenance process, the description of the shape of cooperative relations is based on their level of beneficialness in relation to different types of co-operators. The level of beneficialness was indicated by firms' senior managers according to their subjective perception on the four-grade scale (very unbeneficial, unbeneficial, beneficial and very beneficial). It should be noted that none of the respondents pointed to unbeneficially or very unbeneficially shaped relations with recipients, which can be explained by the fact that the mere existence of relations with customers can be perceived by respondents as a sufficient condition for their beneficialness. The beneficialness in this case is understood as the difference between the effects of a given relationship and the costs associated with it.

The study was conducted in early 2016 on a sample of 97 Polish companies, i.e. companies that are based in the Republic of Poland. The survey questionnaire was sent to 493 randomly selected companies with a request to be filled out by at least representatives of middle management operating in fields related to business development, of which 114 were returned. In the process of verification of the consistency of the received responses, 17 of them were rejected due to inaccuracies and other defects.

\section{The influence of organizational sensory systems on the shape of cooperative relations - presentation of research results}

Firstly, the collation of values of the chi-square independence tests (with p-values) between the characteristics describing the organizational sensory systems and the beneficialness of the shape of the cooperative relations was presented in table 1.

Organizational sensory systems of Polish enterprises in the context of cooperative 
Table 1. The collation of values of the chi-square independence tests (with p-values) between the monitoring frequency of the business environment and internal elements of organizations

\begin{tabular}{|c|c|c|c|}
\hline \multirow{2}{*}{$\begin{array}{l}\text { Areas of surveyed } \\
\text { business entities }\end{array}$} & \multicolumn{3}{|c|}{ The beneficialness of the shape of the cooperative relations with } \\
\hline & suppliers & customers & coopetitors \\
\hline $\begin{array}{l}\text { Production or } \\
\text { services }\end{array}$ & $\begin{array}{l}24.55^{*} \\
(0.0019)\end{array}$ & $\begin{array}{c}7.81 \\
(0.0987)\end{array}$ & $\begin{array}{c}12.13 \\
(0.1453)\end{array}$ \\
\hline Marketing & $\begin{array}{c}4.63 \\
(0.7963)\end{array}$ & $\begin{array}{c}2.60 \\
(0.6275)\end{array}$ & $\begin{array}{c}7.05 \\
(0.5308)\end{array}$ \\
\hline Supply logistics & $\begin{array}{c}13.46 \\
(0.097)\end{array}$ & $\begin{array}{c}4.98 \\
(0.2893)\end{array}$ & $\begin{array}{c}13.42 \\
(0.0983)\end{array}$ \\
\hline Distribution logistics & $\begin{array}{c}2.43 \\
(0.8768)\end{array}$ & $\begin{array}{c}3.88 \\
(0.2747)\end{array}$ & $\begin{array}{c}12.14 \\
(0.0589)\end{array}$ \\
\hline Management & $\begin{array}{c}13.56 \\
(0.0939)\end{array}$ & $\begin{array}{c}5.08 \\
(0.2792)\end{array}$ & $\begin{array}{c}11.24 \\
(0.1885)\end{array}$ \\
\hline $\begin{array}{l}\text { Sales and after sales } \\
\text { services }\end{array}$ & $\begin{array}{c}8.39 \\
(0.3964)\end{array}$ & $\begin{array}{c}3.59 \\
(0.4650)\end{array}$ & $\begin{array}{c}4.71 \\
(0.7877)\end{array}$ \\
\hline $\begin{array}{l}\text { Administration and } \\
\text { supporting actions }\end{array}$ & $\begin{array}{c}4.02 \\
(0.8558)\end{array}$ & $\begin{array}{c}7.59 \\
(0.1078)\end{array}$ & $\begin{array}{c}6.00 \\
(0.6476)\end{array}$ \\
\hline Suppliers & $\begin{array}{c}13.36^{*} \\
(0.0377)\end{array}$ & $\begin{array}{c}2.68 \\
(0.4439)\end{array}$ & $\begin{array}{c}3.16 \\
(0.7886)\end{array}$ \\
\hline Customers & $\begin{array}{c}3.62 \\
(0.7284)\end{array}$ & $\begin{array}{c}6.00 \\
(0.1117)\end{array}$ & $\begin{array}{c}2.45 \\
(0.8745)\end{array}$ \\
\hline Coopetitors & $\begin{array}{c}4.39 \\
(0.6241)\end{array}$ & $\begin{array}{c}1.10 \\
(0.7762)\end{array}$ & $\begin{array}{c}7.32 \\
(0.2919)\end{array}$ \\
\hline
\end{tabular}

Note: The statistically significant chi-squared independence test scores (with a standard significance level of 0.05 ) were bolded and marked with asterisks $\left(^{*}\right)$

Source: own study based on empirical research

It should be noted that only two relationships are statistically significant, and four others, despite their lack of statistical significance, have relatively low p-values. The above analysis was supplemented by a correlation analysis of the Spearman ranks between the frequency of monitoring of the environment and the internal elements of the organization and the level of beneficialness of the shape of cooperative 
relationships separately for suppliers, customers and competitors. This analysis does not include responses indicating the absence of a given area or its surroundings. It turned out that no statistically significant relationships were found.

However, the previously identified relationships (based on the chi squared test) will be presented in two following charts. Note that answers relating to "very unbeneficial" relationships were not included due to lack of indication. Figure 1 shows the relationship between the frequency of monitoring of production or services and the level of beneficialness of the shape of cooperative relationships with suppliers.

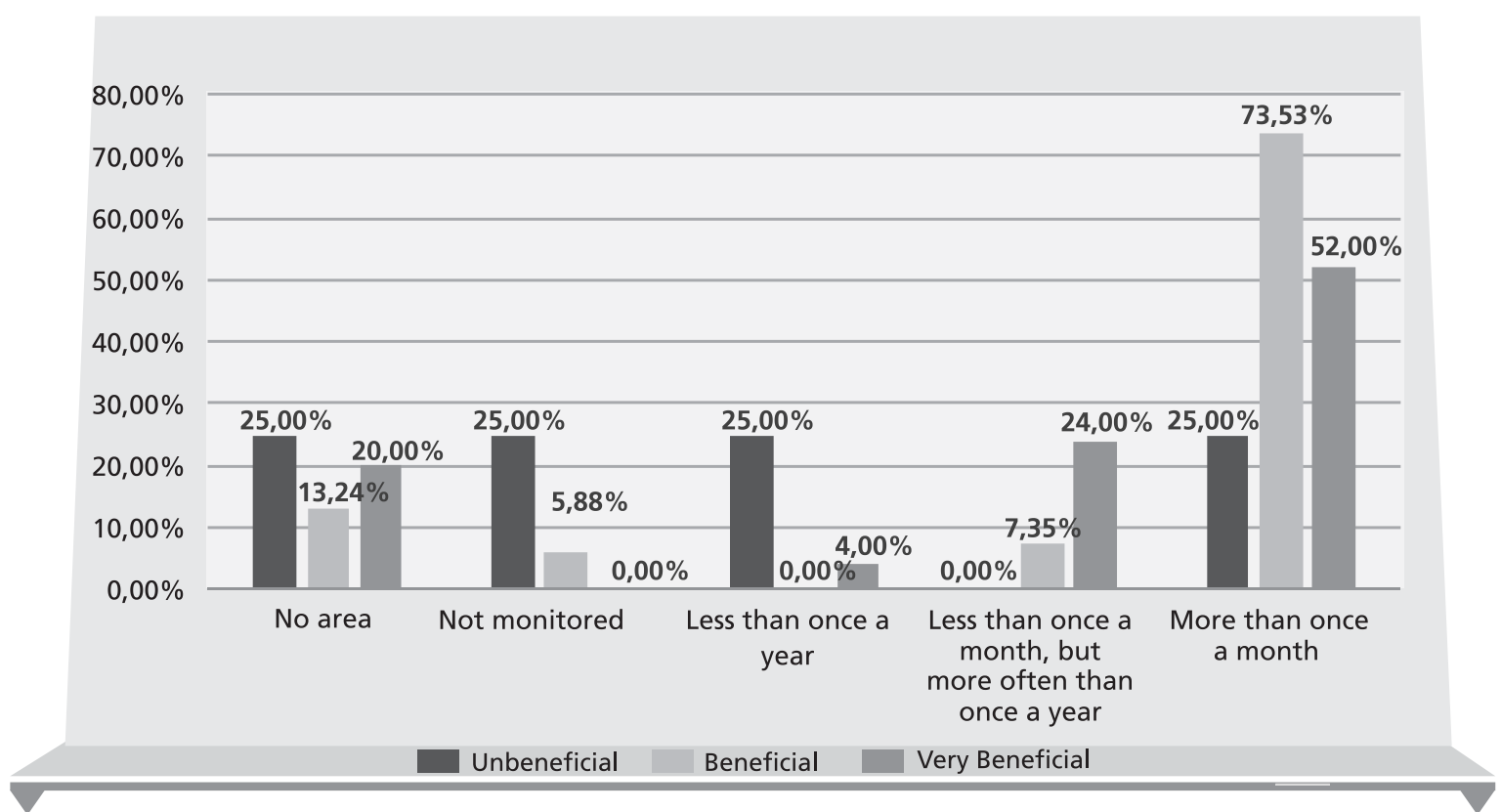

Figure 1. The relationship between the frequency of monitoring of production or services and the level of beneficialness of the shape of cooperative relationships with suppliers

Source: own study based on empirical research

Analysis of the distribution of responses shown in Figure 1 indicates that it is not possible to conclusively determine the existence of a regularity according to which the beneficialness of the shape of cooperative relationships with suppliers increases as the frequency of monitoring of areas of the organizations that are responsible for production or services increases. It should be noted, however, that companies with unbeneficially shaped cooperative relationships with suppliers 
largely monitor this area less than once a year or do not monitor it at all. In turn, as the beneficialness of the shape of cooperative relationships with suppliers increases, the percentage of indications for monitoring of production or services to "less than once a month, but more often than once a year" increases. This chart shows that there is a need for more thorough research in this area, because obtained results are inconclusive.

The figure presented below shows the relationship between the frequency of supplier monitoring and the level of beneficialness of the shape of cooperative relationships with suppliers.

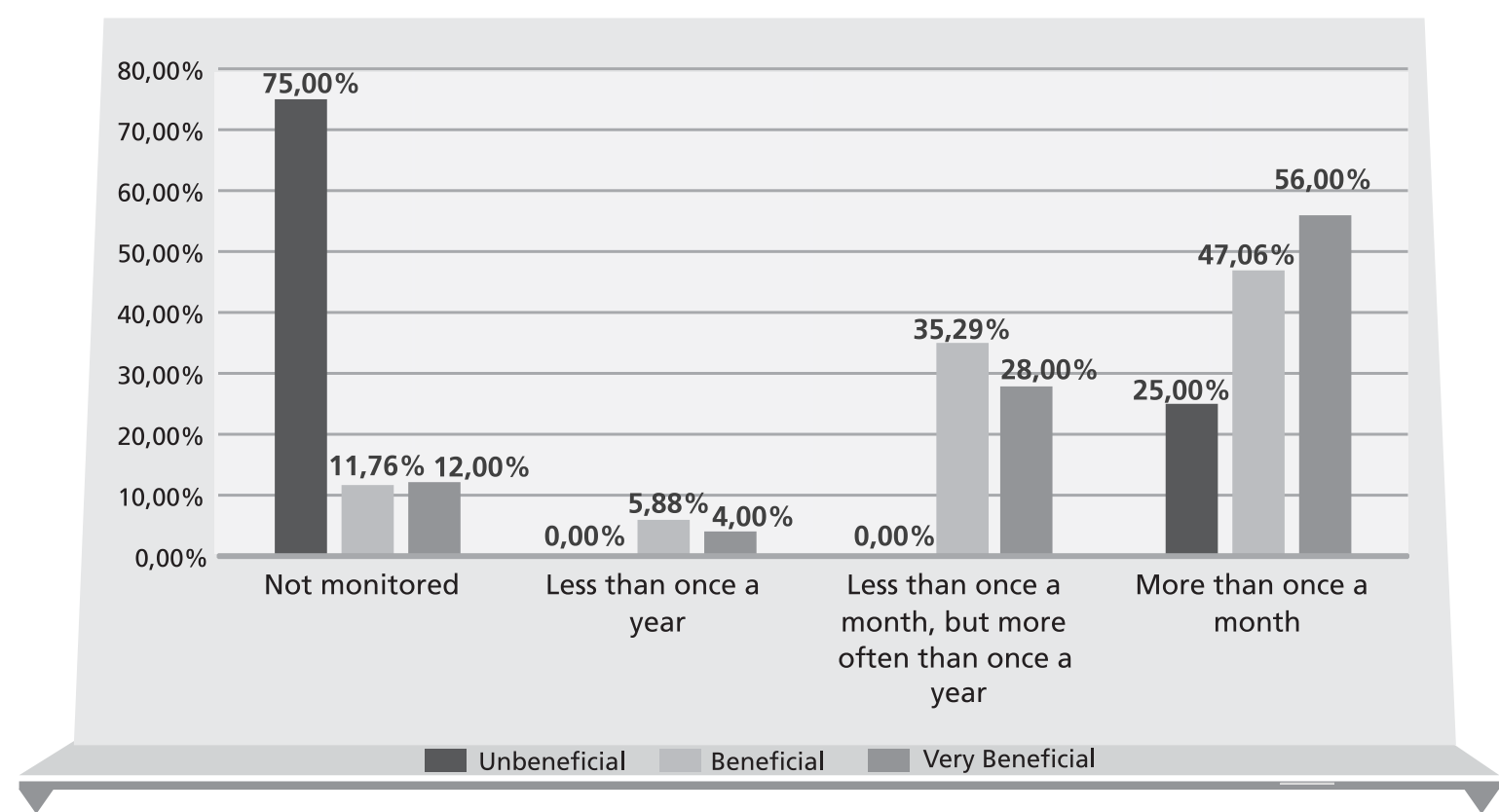

Figure 2. The relationship between the frequency of monitoring of suppliers and the level of beneficialness of the shape of cooperative relationships with suppliers

Source: own study based on empirical research

Analysis of the distribution of responses shown in Figure 2 indicates a regularity, which shows that the beneficialness of the shape of cooperative relationships with suppliers increases along the increase in monitoring frequency of suppliers. In the case of unbeneficially shaped cooperative relationships with suppliers, the vast majority of companies do not monitor their suppliers at all. Companies that more closely monitor their suppliers have the ability to identify 
more distressing signals that may lead to changes in the process of adaptation or termination (in the event of inability to make changes) of those relationships. The rapid reaction and adoption of the necessary actions (whether adaptive or related to the termination of the relationship) translates into the beneficial shape of cooperative relationships with suppliers. There is also one more noteworthy observation - there is no statistically significant relationship between the beneficialness of the cooperative relationships with other cooperators and the frequency of monitoring them. This finding is counterintuitive, because it would be expected that frequent monitoring of buyers allows to identify their needs more accurately and in consequence allows to satisfy them better.

\section{Conclusions}

The results presented in this study support a claim that the shape of organizational sensory system influences the beneficialness of cooperative relationships. However, this influence is limited only to the relationships with the suppliers and occurs only in areas of the organizational sensory system pertaining to the production or services (basic operations) and suppliers themselves. The fact that this kind of relationship is not present between the monitoring frequency of other cooperators and the beneficialness of cooperative relationships with them is noteworthy and cannot be entirely explained. The nature of those relationships is elusive and in case of the production or services area cannot be even conclusively identified. The research was probably biased by subjectivity of answers. In addition, people indicated to answer questions may not have had sufficient knowledge in the area under examination. The more thorough research in this area is recommended in order to identify and analyze these relationships to a greater degree. Future research in this area should focus on deeper links between the structure of the sensory system and the beneficialness of cooperative relationships.

\section{Summary}

Organizational sensory systems of Polish enterprises in the context of cooperative relationships

The aim of this paper is to indicate the relationship between the shape of organizational sensory systems of Polish companies and beneficialness of the shape of cooperative relations between these companies with particular kinds of cooperators. The theoretical part of this article was devoted to the identification of the role of

Organizational sensory systems of Polish enterprises in the context of cooperative 
cooperative relations in the contemporary economic environment and a brief description of the concept of organizational sensory system, including its influence on cooperation between companies. The survey used the respondents' indications of frequency of monitoring of elements of organization and its environment and the indication of the beneficialness of the shape of cooperative relationships with suppliers, customers and co-opetitors (in the framework of coopetitive relations). The chi-squared independence tests were used to demonstrate dependencies. In conclusion, it turned out that there are only two statistically significant relations and both of them pertain to relationships with customers.

Keywords: organizational sensory system, environmental monitoring, internal monitoring, cooperative relationships.

\section{Streszczenie}

\section{Organizacyjne systemy sensoryczne polskich przedsiębiorstw} w kontekście relacji kooperacyjnych

Celem niniejszego artykułu jest wskazanie na relacje pomiędzy kształtem organizacyjnych systemów sensorycznych polskich przedsiębiorstw a korzystnością ukształtowania relacji kooperacyjnych tych przedsiębiorstw z poszczególnymi rodzajami kooperantów. Część teoretyczna niniejszego opracowania identyfikuje role relacji kooperacyjnych we współczesnych uwarunkowaniach gospodarczych oraz syntetycznie przedstawia koncepcję organizacyjnego systemu sensorycznego, uwzględniając jego wpływ na kooperację między przedsiębiorstwami. W ramach badań wykorzystano wskazania respondentów na częstotliwość monitorowania elementów organizacji i jej otoczenia, a także wskazań na poziom korzystności ukształtowania relacji kooperacyjnych z dostawcami, odbiorcami oraz konkurentami ( $w$ ramach relacji koopetycji). Przeprowadzono testy niezależności chi-kwadrat, w celu wskazania na zaistniałe relacje. Wyniki badań wskazują na istnienie dwóch statystycznych zależności w obszarze relacji z odbiorcami.

\section{Słowa}

kluczowe: organizacyjny system sensoryczny, monitoring otoczenia, monitoring wnętrza organizacji, relacje kooperacyjne. 


\section{JEL}

\section{Classification: L14, M10, M12, M14}

\section{References}

1. Anderson, J.C., Narus, J.C. (1991). A Model of the Distributor's Perspective of Distributor-Manufacturer Working Relationships, Journal of Marketing, vol. 48 , No. 4.

2. Barringer, B.R., Harrison, J.S. (2000). Walking a Tightrope: Creating Value Through Interorganizational Relationships, Journal of Management, vol. 26, No. 3.

3. Dyer, J.H., Nobeoka, K. (2000). Creating and Managing a High Performance Knowledge-Sharing Network: The Toyota Case, Strategic Management Journal, No. 21.

4. Lane, C., Bachmann, R. (1997). Cooperation in inter-firm relations in Britain and Germany: the role of social institutions, British Journal of Sociology, No. 2(48).

5. Latusek-Jurczak, D. (2014). Sieci międzyorganizacyjne jako struktury wspótpracy - podstawowe pojęcia analityczne. In: Koźmiński, A.K., LatusekJurczak, D. (eds.), Relacje międzyorganizacyjne w naukach o zarządzaniu, Wolters Kluwer, Warszawa.

6. Okada, Y. (2008). From Vertical to Horizontal Inter-Firm Cooperation: Dynamic Innovation in Japan's Semiconductor Industry, Asia Pacific Business Review, No. 3(14).

7. Oliver, Ch. (1990). Determinants of interorganizational relationships: Integration and future directions, Academy of Management Review, vol. 15, No. 2.

8. Porac, J.F., Ventresca, M.J., Mishina, Y. (2002). Interorganizational cognition and interpretation, Companion to Organizations.

9. Ritter, T., Wilkinson, I.F., Johnston, W.J. (2004). Managing in Complex Business Networks, Industrial Marketing Management, vol. 33.

10. Sako, M. (1992). Prices, Quality and Trust: Inter-firm Relations in Britain and Japan, Cambridge University Press, Cambridge.

11. Ebers, M. (1997). Explaining inter-organizational network formation, The formation of inter-organizational networks, No. 1.

12. Urban, S., Vendemini, S. (1992). European Strategic Alliances. Co-operative Corporate Strategies in the New Europe, Blackwell Business, Oxford.

13. Urbanowska-Sojkin, E. (2003). Zarządzanie przedsiębiorstwem. Od kryzysu do sukcesu, wyd. Akademii Ekonomicznej w Poznaniu, Poznań.

14. Wójcik-Karpacz, A. (2012). Zdolność relacyjna w tworzeniu efektów wspótdziatania małych $i$ średnich przedsiębiorstw, Oficyna Wydawnicza SGH, Warszawa. 